\title{
Angiopoietin like protein 3 (Angptl3), fatty acid binding protein 4 (FABP4) and homeostasis model assessment of insulin resistance (HOMA-IR) among Indonesian obese non diabetic males
}

\author{
Yani Lina, ${ }^{1,2}$ Gatot S. Lawrence, ${ }^{1}$ Andi Wijaya, ${ }^{1,2}$ Suryani As'ad ${ }^{1}$ \\ ${ }^{1}$ Doctoral Program, Faculty of Medicine, Hassanuddin University, Makassar, Indonesia \\ ${ }^{2}$ Prodia Clinical Laboratory, Indonesia
}

\begin{abstract}
Abstrak
Tujuan Untuk meneliti korelasi antara penanda biokimia Angptl3, FABP4 dan HOMA-IR pada populasi pria Indonesia dengan kondisi obesitas sentral non diabetes.

Metode Penelitian ini menggunakan metode potong lintang pada 133 individu pria dengan obesitas sentral non diabetes (dengan kriteria lingkar pinggang $>90 \mathrm{~cm}$; konsentrasi glukosa darah puasa $<126 \mathrm{mg} / \mathrm{dL}$; dan tidak adanya keluhan khas diabetes) usia 30-60 tahun yang dilakukan di Jakarta, Indonesia. Penanda biokimia yang ditentukan meliputi Angptl3, FABP4, FFA, insulin puasa, dan glukosa puasa. Di samping itu dilakukan penentuan berat badan, tinggi badan, lingkar pinggang (LP), tekanan darah sistolik (TDS), dan tekanan darah diastolik (TDD). Hubungan antara berbagai penanda biokimia didapatkan melalui uji korelasi Pearson dan Spearman.

Hasil Hasil uji korelasi Pearson dan Spearman menunjukkan adanya korelasi positifyang bermakna antara Angptl3 dan FABP4 $(r=0,319 ; P=0,000)$, Angptl3 dan FFA $(r=0,171 ; P=0,049)$, FABP4 dan HOMA-IR $(r=0,202 ; P=0,019)$, FFA dan FABP4 $(r=0,506 ; P=0,000), L P$ dan HOMA-IR $(r=0,323 ; P=0,000), L P$ dan FABP4 $(r=0,387 ; P=0,000)$, Indeks Massa Tubuh (IMT) dan HOMA-IR ( $r=0,270 ; P=0,002)$, serta IMT dan FABP4 $(r=0,362 ; P=0,000)$.

Kesimpulan Adanya korelasi positif yang bermakna antara Angptl3-FABP4, Angptl3-FFA, FFA-FABP4 serta FABP4HOMA-IR menimbulkan dugaan bahwa Angptl3 memicu lipolisis dalam jaringan adiposa melalui hubungannya dengan FABP4 serta berhubungan dengan peningkatan resistensi insulin pada individu pria obes non diabetes. (Med J Indones 2010; 19: 185-90)
\end{abstract}

\begin{abstract}
Aim To reveal the correlation between Angpt13, FABP4 and HOMA-IR among Indonesian obese non diabetic males.

Methods This is a cross sectional study with 133 obese non diabetic males volunteers (characterized by waist circumference $>90 \mathrm{~cm}$; fasting blood glucose $<126 \mathrm{mg} / \mathrm{dL}$; and no diabetic specific symptoms) age between 3060 years which was done in Jakarta, Indonesia. We measured biochemical markers such as Angptl3, FABP4, FFA, fasting insulin and fasting glucose. We also measured weight, height, waist circumference (WC), systolic blood pressure (SBP) and diastolic blood pressure (DBP). Correlation between each marker was measured using Pearson and Spearman's analysis.

Results Pearson and Spearman's correlation analysis showed significant positive correlation between Angptl3 and FABP4 $(r=0.319 ; \mathrm{P}=0.000)$, Angptl3 and FFA $(\mathrm{r}=0.171 ; \mathrm{r}=0.049)$, FABP4 and HOMA-IR $(\mathrm{r}=0.202 ; \mathrm{P}=0.019)$, FFA and FABP4 $(\mathrm{r}=0.506 ; \mathrm{P}=0.000)$, WC and HOMA-IR $(\mathrm{r}=0.323 ; \mathrm{P}=0.000)$, WC and FABP4 $(\mathrm{r}=0.387 ; \mathrm{P}=$ $0.000)$, Body Mass Index (BMI) and HOMA-IR $(\mathrm{r}=0.270 ; \mathrm{P}=0.002)$, BMI and FABP4 $(\mathrm{r}=0.362 ; \mathrm{P}=0.000)$.

Conclusion This study showed positive significant correlations between Angptl3-FABP4, Angptl3-FFA, FFA-FABP4 and FABP4-HOMA-IR. We suggest that Angptl3 can activate lipolysis in adipose tissue (through its correlation with FABP4), and Angptl3 concentration is related to insulin resistance risk among Indonesian obese non diabetic males. (Med J Indones 2010; 19: 185-90)
\end{abstract}

Key words: Angptl3, FABP4, HOMA-IR, insulin resistance, lipolysis, obesity

In recent years, there has been a rapid escalation worldwide in the prevalence of overweight and obesity. Indonesian Family Life Survey 3 year 2000 with study size to 20.593 individuals age $\geq 20$ years shown that obesity prevalence in male is $1.3 \%$ and in female is $4.5 \%{ }^{1}$

Obesity is closely associated with insulin resistance and increased plasma free fatty acid (FFA). FAlevel is known

Correspondenceemail to: yani_lina1979@yahoo.com can cause insulin resistance in skeletal muscle, liver, and endothelial cells. Plasma levels of FFA are commonly higher in obese compared to non obese people. The reason, for this includes an increased number of fat cells, a decrease in FFA clearance and at a later stage, insulin resistance at the adipose tissue level, resulting in increased lipolysis. It has been shown that increase plasma FFA concentration results in intramyocellular 
accumulation of triglycerides and several intermediate compounds generated during triglyceride synthesis including long chain acyl-CoA and diacylglycerol (DAG). Of those, DAG is of particular interest because it is a strong allosteric activator of protein kinase $\mathrm{C}$ (PKC). PKC can increase serine phosphorylation and decrease tyrosine phosphorylation of insulin receptor substrate (IRS)-1 thereby interrupting insulin signaling and causing insulin resistance. ${ }^{2}$

Intracellular lipid chaperones known as fatty acid binding proteins (FABPs) are a group of molecules that coordinate lipid responses in cells and are also strongly linked to metabolic and inflammatory pathways. FABPs are abundantly expressed $14-15 \mathrm{kDa}$ proteins that reversibly bind hydrophobic ligands, such as saturated and unsaturated long-chain fatty acids, eicosanoids and other lipids, with high affinity. Expression of adipocyte fatty acid-binding protein (FABP4) in adipocytes has been shown will promote lipolysis, increase tumor necrosis factor (TNF)- $\alpha$ expression, and contribute to insulin resistance. Macrophage FABP4 may influence foam cell formation and atherogenesis through effects on FFA shuttling that promote increased cholesteryl ester (CE) formation and/or effects on gene transcription that promote the production of inflammatory cytokines..$^{3-4}$

Angiopoetins (ligands for the TIE tyrosine kinase receptors (TIE1 and TIE2)), play roles in angiogenesis and hematopoiesis, and have two structural domains, a coiled-coil domain and a fibrinogen-like domain. Angiopoietin-like proteins (Angptls) are orphan ligands with structural similarity to angiopoetins. Angptl3 is now understood to be a hepatocyte-derived circulating factor that regulate lipid metabolism. Angptl3 mRNA expression is restricted to the liver, but Angptl3 protein is found in the circulation suggesting a systemic role in vivo. Angptl3 expression in the liver and Angptl3 plasma levels are increased in a mouse model of diabetes mellitus and decreased by leptin and insulin treatment, suggesting a role in diabetes. Shimamura's study revealed that Angptl3 targeted on adipose cells directly (Angptl3 was able to bind to adipocytes) and enhanced the lipolysis, leading to increased release of FFA and glycerol from adipose cells. Angptl3 decreases very low density lipoprotein (VLDL) triglyceride clearance by inhibiting lipoprotein lipase (LPL) activity. Angptl3 also involved in the regulation of plasma HDL cholesterol levels through the inhibition of endothelial lipase (EL) activity. These observations indicate that Angptl3 might regulate lipid metabolism by inhibiting LPL and EL, and by stimulating lipolysis in adipocytes. ${ }^{5-8}$
The HOMA model is used to yield an estimate of insulin sensitivity and $\beta$-cell function from fasting plasma insulin and glucose concentrations. The equations are widely used and simplify to: HOMA-IR $=($ FPI $x$ FPG)/22.5 for insulin resistance (IR), in which where FPI is fasting plasma insulin concentration $(\mathrm{mU} / \mathrm{l})$ and FPG is fasting plasma glucose $(\mathrm{mmol} / \mathrm{l}) .{ }^{9}$

Although it is known that Angptl3 and FABP4 correlate with lipolysis, studies are limited in mice. We hypothesized that there is a correlation between Angptl3 and FABP4 in adipocyte that inhibit LPL activity and stimulate lipolysis in adipocytes. Because Angptl3 concentration also increase in diabetes, we suggest that Angpt13 is one of the factors that increases insulin resistance risk through increasing lipolysis. We used obese males as samples because obesity, especially central obesity, is associated with insulin resistance risk through increased lipolysis process. There is no study which measured correlation between Angptl3, FABP4 and insulin resistance among obese non diabetic males. Therefore, the aim of this study is to reveal the correlation between Angpt13, FABP4 and HOMA-IR among Indonesian obese non diabetic males.

\section{METHODS}

\section{Study Design}

We used cross sectional study to 133 obese male volunteers. Data collection was commenced in January 2009 and completed in June 2009. The study proposal has been approved by the Health Research Ethics Committee of the Faculty of Medicine, University of Hasanuddin, Makassar, Indonesia.

\section{Subjects}

Subjects were recruited from Prodia Clinical Laboratory in Jakarta for general medical check-up, employees and relatives of Prodia Clinical Laboratory in Jakarta. Subjects were apparently healthy male, aged 30-60 years old, with WC $>90 \mathrm{~cm}$ (according to International Diabetes Federation criteria); fasting blood glucose < $126 \mathrm{mg} / \mathrm{dL}$ and no diabetic specific symptoms such as polydipsia, polyphagia, polyuria and weight loss (according to Perkumpulan Endokrinologi Indonesia 2006 criteria); and willing to follow the study protocol, were considered eligible to be included in the study. 
Subjects who were consuming steroids or antioxidant supplements, such as vitamins $\mathrm{C}$ and or $\mathrm{E}$, green tea or other supplements known as antioxidants for the last 3 weeks; or had been treated with anti-inflammatory drugs such as statins or thiazolidinedione for the last 3 weeks; or had liver dysfunction, kidney dysfunction, asthma, fever, and other acute inflammation were excluded from the study. Each subject was provided with explanation about the study, and signed informed consent prior to commencement of the study.

\section{Anthropometric Measurement}

Body weight (BW) was measured in kilograms to the nearest $0.1 \mathrm{~kg}$, with light clothes on, using a beam scale (Tanita, Japan). Height (Ht) was measured in centimeters to the nearest $0.1 \mathrm{~cm}$, in standing position with socks and shoes removed, using a microtois (stature meter). WC was measured in centimeters to the nearest $0.1 \mathrm{~cm}$, using a flexible non-elastic tape (Roche, Switzerland). WC was measured at the midway region between the lowest rib margin and the iliac crest, in standing position with abdomen relaxed, feet together and weight equally divided over both legs. BMI was calculated by dividing body weight (in $\mathrm{kg}$ ) by height squares (in squared meter).

\section{Blood Pressure Measurement}

Blood pressure was measured using a sphygnomanometer during the course of the study. Subjects were seated for at least $5 \mathrm{~min}$ before the actual measurement was taken. The first Korotkoff sound represented systolic blood pressure and the fifth Korotkoff sound (when sound just disappears) was taken as the diastolic blood pressure. Two measurements were taken with $5 \mathrm{~min}$ interval, and the average value was noted.

\section{Biochemical Assessment}

Fasting blood samples were collected in the morning between 07:00 and 10:00 am. Plasma and serum were separated immediately by centrifugation and the aliquots were frozen at $-20^{\circ} \mathrm{C}$ for subsequent batched analysis for Angptl3 and FABP4. Fasting insulin, fasting glucose, hsCRP, creatinine, alanine amino transferase (ALT) and aspartate amino transferase (AST) levels were assayed by the Prodia Clinical Laboratory's routine chemistry procedures. Serum AST, ALT and creatinine were determined using the International Federation of Clinical Chemistry (IFCC) method and reagents manufactured by Roche (Mannheim, Germany). The standard automated glucose oxidase method was used to determined glucose, reagents manufactured by Roche (Mannheim, Germany). The concentration of CRP was determined using a high-sensitivity chemiluminescent assay on the Immulite $^{\circledR}$ (Dade-Behring, Los Angeles, CA, USA). Fasting insulin was measured using ultrasensitive insulin ELISA from Mercodia. FABP4 and Angptl3 were measured using an enzyme-linked immunoassay (ELISA) kit from Biovendor.

\section{Data Analysis}

Data analysis was done using SPSS 11.5 statistical analysis for Windows (SPSS Inc., Chicago, IL, USA). Distributions of continuous variables were assessed for normality using the Kolmogorov-Smirnov. Associations between variables were analyzed using Pearson and Spearman's correlation analysis. All tests were twosided and considered significant at $p<0.05$.

\section{RESULTS}

Table 1 showed the details of anthropometric measurements (height, weight, BMI, WC, and blood pressure); measurement of routine biochemical variables (fasting glucose, fasting insulin, creatinine, hsCRP, SGPT and SGOT), measurement of Angpt13, FFA and FABP4.

Table 2 presents the Pearson and Spearman's correlation analysis. Figure 1 presents correlation between FFA and FABP4.

Table 1. Basic Clinical, Anthropometric and Biochemical Characteristics of Volunteers

\begin{tabular}{lccccc}
\hline & $\mathrm{N}$ & Minimum & Maximum & Mean & SD \\
\hline Age (years) & 133 & 30.00 & 56.00 & 38.56 & 5.69 \\
SBP (mmHg) & 133 & 90.00 & 150.00 & 114.93 & 13.62 \\
DBP (mmHg) & 133 & 60.00 & 110.00 & 76.17 & 9.98 \\
Height (cm) & 133 & 156.00 & 185.00 & 166.29 & 5.20 \\
Weight (kg) & 133 & 65.00 & 120.00 & 79.69 & 8.10 \\
WC (cm) & 133 & 91.00 & 126.00 & 97.37 & 5.60 \\
Triglyceride (mg/dL) & 133 & 42.00 & 2067.00 & 202.43 & 209.95 \\
SGOT (U/L) & 133 & 16.00 & 60.00 & 29.01 & 8.23 \\
SGPT (U/L) & 133 & 14.00 & 84.00 & 37.53 & 14.34 \\
FPG (mg/dL) & 133 & 74.00 & 119.00 & 90.06 & 8.74 \\
Creatinine (mg/dL) & 133 & 0.06 & 1.40 & 1.09 & 0.16 \\
FPI (uIu/mL) & 133 & 2.00 & 38.50 & 8.59 & 5.17 \\
FFA (mM) & 133 & 0.18 & 1.12 & 0.59 & 0.19 \\
FABP4 (ng/mL) & 133 & 11.38 & 49.53 & 25.46 & 7.57 \\
Angptl3 (ng/mL) & 133 & 139.10 & 600.60 & 319.08 & 89.25 \\
HOMA-IR & 133 & 0.43 & 7.03 & 1.92 & 1.16 \\
BMI & 133 & 23.88 & 44.08 & 28.83 & 2.78 \\
hsCRP & 133 & 0.22 & 9.12 & 2.24 & 1.83 \\
& & & & & \\
\hline
\end{tabular}

Description: $\mathrm{SBP}=$ systolic blood pressure; $\mathrm{DBP}=$ diastolic blood pressure; $\mathrm{BMI}$ = body mass index; FPG $=$ fasting plasma glucose; hsCRP $=$ high sensitivity $\mathrm{C}$ re active protein; $\mathrm{WC}=$ waist circumference; $\mathrm{FPI}=$ fasting plasma insulin 
Table 2. Pearson and Spearman's Correlation Analysis

\begin{tabular}{cccccccc}
\hline & WC & FABP4 & Angpt13 & HOMA-IR & BMI & FFA & Triglyceride \\
\hline WC (r) & 1.000 & $0.387^{* *}$ & 0.160 & $0.323^{* *}$ & $0.270^{* *}$ & $0.291^{* *}$ & 0.121 \\
(p) & - & 0.000 & 0.067 & 0.000 & 0.002 & 0.001 & 0.167 \\
FABP4 (r) & $0.387^{* *}$ & 1.000 & $0.319^{* *}$ & $0.202^{*}$ & $0.362^{* *}$ & $0.506^{* *}$ & 0.094 \\
(p) & 0.000 & - & 0.000 & 0.019 & 0.000 & 0.000 & 0.281 \\
Angpt13 (r) & 0.160 & $0.319^{* *}$ & 1.000 & 0.068 & 0.169 & $0.171^{*}$ & $0.201^{*}$ \\
(p) & 0.067 & 0.000 & - & 0.434 & 0.052 & 0.049 & 0.020 \\
HOMA-IR (r) & $0.323 * *$ & $0.202^{*}$ & 0.068 & 1.000 & $0.270^{* *}$ & 0.047 & $0.229^{* *}$ \\
(p) & 0.000 & 0.019 & 0.434 & - & 0.002 & 0.590 & 0.008 \\
BMI (r) & $0.749^{* *}$ & $0.362^{* *}$ & 0.169 & $0.270^{* *}$ & 1.000 & $0.237^{*}$ & 0.067 \\
(p) & 0.000 & 0.000 & 0.052 & 0.002 & - & 0.006 & 0.444 \\
FFA (r) & $0.291 * *$ & $0.506^{* *}$ & $0.171^{*}$ & 0.047 & $0.237 *$ & 1.000 & 0.003 \\
(p) & 0.001 & 0.000 & 0.049 & 0.590 & 0.006 & - & 0.975 \\
Triglyceride (r) & 0.121 & 0.094 & $0.201 *$ & $0.229 * *$ & 0.067 & 0.003 & 1.000 \\
(p) & 0.167 & 0.281 & 0.020 & 0.008 & 0.444 & 0.975 & - \\
\hline
\end{tabular}

$* *$ significant correlation at $\mathrm{p}<0.01$ (2-tailed)

$*=$ significant correlation at $\mathrm{p}<0.05$ (2-tailed)

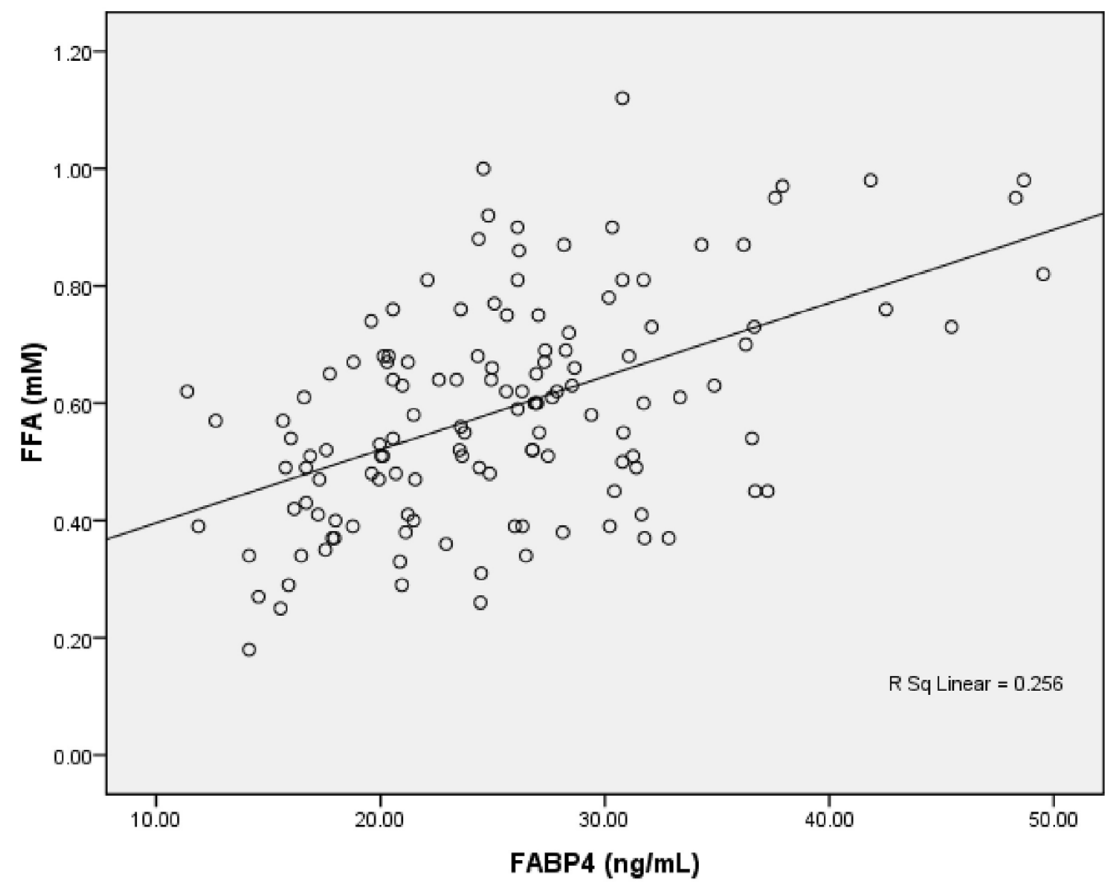

Figure 1. Correlation between FFA and FABP4

\section{DISCUSSION}

Obesity, especially central obesity is associated with insulin resistance, dyslipidemia, and systemic inflammation, which play essential roles in the pathogenesis of cardiovascular disease (CVD), metabolic syndrome, and certain cancers. Although it is still being debated, it has nevertheless become clear that elevated plasma levels of FFA are a major link between obesity and insulin resistance/T2DM. ${ }^{2}$
In this study we found that obesity which is shown by increased WC and BMI were associated with FFA, FABP4 and HOMA-IR. Our study confirmed previous studies that obesity was related to increasing insulin resistance risk through increased lipolysis. Exposure to excess FAresults in the accumulation of intramyocellular lipid species such as DAG and ceramides. DAG is thought to activate serine kinases that can cause serine phosphorylate and reduces the signal transduction capacity of IRS-1. Ceramides can interfere with insulin signalling at the level of Akt and are produced de novo 
from FA or by release from sphingolipids in response to stress cytokines such as TNF. TNF and other cytokines associated with fat accumulation can also activate serine kinases directly via inflammatory signalling pathways. Excess FA oxidation in the mitochondria, via the tricarboxylic acid (TCA) cycle and the electron transport chain (ETC), can lead to an increase in FA metabolites and reactive oxygen species (ROS) which can activate intracellular stress kinases but may possibly have effects on insulin signalling to glucose transporter 4 (GLUT4) translocation. ${ }^{10}$

Observations on FABP null mice raised the concept of an interesting biological role for FABPs as a potential central regulator of common pathways controlling inflammatory and metabolic signaling. In this study, we found a significant correlation between FFA and FABP4 because FABP4 is the major cytosolic protein of mature adipocytes, small, lipid-binding protein proteins that reversibly bind hydrophobic ligands, such as saturated and unsaturated long-chain fatty acids, eicosanoids and other lipids, with high affinity. Although A-FABP was traditionally thought to be a cytoplasmic protein, recent studies showed that a significant portion of this protein also is released from adipocytes into the bloodstream. FABP4 is known contribute to insulin resistance through increased lipolysis and TNF- $\alpha$ expression. ${ }^{11-13}$

Angptl3 is also known as lipolytic factor, and this study shown that WC and BMI have positive correlation with Angptl3 although it is not significant statistically. Angptl3 has a significant positive correlation with FFA and FABP4, suggested that Angptl3 activates lipolysis and contributes to insulin resistance, through another factor such as FABP4.

Lipolysis is a complex metabolic process carried out by adipocytes during times of nutrient deprivation and/or stress in which fatty acids and glycerol are liberated from the triacylglycerol storage droplet and released from the cell. Although described in detail in several excellent reviews, the salient features of the regulatory processes controlling lipolysis include $\mathrm{G}$ protein-coupled receptor activation of protein kinase $\mathrm{A}$ and subsequent phosphorylation of two key proteins: the droplet associated perilipin A and the cytoplasmic hormone-sensitive lipase (HSL). Phosphorylation of perilipin A allows for an ill defined dynamic restructuring of droplet surface architecture, redistribution of perilipin A to smaller microdroplets, and concomitant translocation of the lipase to the lipid surface where it gains access to its substrate. HSL is responsible for almost $50 \%$ of the fatty acids generated by white adipose tissue triacylglycerol hydrolysis and is the rate-limiting enzyme in lipolysis. ${ }^{14}$

Liver-specific Angptl3 protein directly targets on adipose cells and enhances the lipolysis, resulting in the increased release of FFA and glycerol from adipose cells. But the mechanism of how Angptl3 enhance the lipolysis remains unclear. Our study showed that there was a correlation between Angptl3 and FABP4 among obese non diabetic males. According to Boord's study, expression of FABP4 in adipocytes has been shown to promote lipolysis and contribute to insulin resistance.

Jun Shen's study showed that HSL interact with FABP4. Deletional mutations of HSL localized the region of HSL that interacts with FABP4 to amino acids 192-200, and site-directed mutagenesis of individual amino acids in this region identified His-194 and Glu-199 as critical for mediating the interaction of HSL with FABP4. It appears that FABP4 can increase the hydrolytic activity of HSL through its ability to bind and sequester fatty acids and through its specific protein-protein interaction, perhaps leading to a conformational change or steric effects on HSL. Evidence that these functional effects of the interaction of FABP4 with HSL occur in vivo is supported by experiments on FABP4-null mice. In the absence of FABP4, intracellular free fatty acid concentrations are increased in adipose cells, and basal and isoproterenol-stimulated lipolysis are decreased almost $40 \%$ or to a similar degree suggested by in vitro and cell experiments. Thus Jun Shen's observations are consistent with the proposal that FABP4 and HSL constitute a lipolytic complex. This complex functionally results on an increase in hydrolytic activity of HSL brought about by the physical interaction of HSL with FABP4 and by the ability of FABP4 to bind and sequester fatty acids. Thereby, lipolysis and intracellular trafficking of fatty acids are controlled in an organized fashion. ${ }^{15}$

We suggested that association between Angpt13 and FABP4 mediates the lipolytic action of Angptl3 on adipocytes. Shimamura showed that there is specific bindings of Angptl3 to adipose cells (using fluorescense-labeled protein visually and ${ }^{125}$ I-labeled protein by the binding analysis). The binding of Angptl3 to adipose cells and association of Angpt13-FABP4 might activate the lipolytic complex between FABP4 and HSL results in an increase in the hydrolytic activity of HSL. According to ours and the previous studies, FABP4 is an independent risk factor for insulin resistance. We 
conclude that Angptl3 may activate lipolysis in adipose tissue through FABP4 (activates FABP4-HSL complex) and contribute to insulin resistance risk among obese non diabetic males.

In conclusion, this study showed there were positive significant correlations between Angptl3-FABP4, Angpt13FFA, FFA-FABP4, and FABP4-HOMA-IR. We suggest that Angptl3 can activate lipolysis in adipose tissue (through its correlation with FABP4), and Angptl3 concentration is related to insulin resistance risk among Indonesian obese non diabetic males.

\section{Acknowledgments}

This study was funded by the Prodia Foundation for Research and Training. We are indebted to the technical staff of the Prodia Clinical Laboratory, Clinical Trial, Research and Development Departments for their valuable assistance in undertaking specimen collection and biochemical assessments.

\section{REFERENCES}

1. Asia Pacific Cohort Studies Collaboration. The burden of overweight and obesity in the Asia-Pacific region. Obes Rev. 2007; 8: 191-6

2. Boden G. Free fatty acid as target for therapy. Curr Opin Endocrinol Diabetes. 2004; 11: 258-63

3. Furuhashi M, Hotamisligil GS. Fatty acid binding proteins : role in metabolic diseases and potential as drug targets. Nat Rev Drug Discov. 2008; 7: 489-503

4. Boord JB, Fazio S, Linton MF. Cytoplasmic fatty acidbinding protein: emerging roles in metabolism and atherosclerosis. Curr Opin Lipidol. 2002; 13: 141-7
5. Oike Y, Akao M, Kubota Y, Suda T. Angiopoietin-like proteins: potencial new targets for metabolic syndrome therapy. Trends Mol Med. 2005; 11: 473-9

6. Hato T, Tabata M, Oike Y. The role of angiopoietin-like proteins in angiogenesis and metabolism. Trends Cardiovasc Med. 2008; 18: 6-14

7. Shimamura M, Matsuda M, Kobayashi S, Ando Y, Ono M, Koishi R, et al. Angiopoietin-like protein 3, a hepatic secretory factor, activates lipolysis in adipocyte. Biochem Biophys Res Commun. 2003; 301: 604-9

8. Shimamura M, Matsuda M, Yasumo H, Okazaki M, Fujimoto K, Kono K, et al. Angiopoietin-like protein3 regulates plasma HDL cholesterol through suppression of endothelial lipase. Arterioscler Thromb Vasc Biol. 2007; 27: 366-72

9. Wallace TM, Levy JC, Matthews DR. Use and abuse of HOMA-IR modeling. Diab Care. 2004; 27: 1487-95

10. Kraegen EW, Cooney GJ. Free fatty acids and skeletal muscle insulin resistance. Curr Opin Lipidol. 2008; 19: 235-41

11. Makowski L, Hotamisligil HS. Fatty acid binding proteins the evolutionary crossroads of inflammatory and metabolic responses. J Nutr. 2004; 134: 2464S-8S

12. Xu A, Tso AWK, Cheung BMY, Wang Y, Wat NMS, Fong $\mathrm{CHY}$, et al. Circulating adipocyte-fatty acid binding protein levels predict the development of the metabolic syndrome: a 5-year prospective study. Circulation. 2007; 115: 1537-43

13. Furuhashi M, Hotamisligil GS. Fatty acid-binding proteins : role in metabolic diseases and potential as drug targets. Nat Rev Drug Discov. 2008; 7: 489-503

14. Jenkins-Kruchten AE, Bennaars-Eiden A, Ross JR, Shen WJ, Kraemer FB, Bernlohr DA. Fatty-acid binding proteinhormone sensitive lipase interaction. J Biol Chem. 2003; 278: 47636-43

15. Jun Shen W, Liang Y, Hong R, Patel S, Natu V, Sridhar $\mathrm{K}$, et al. Characterization of the functional interaction of adipocyte lipid-binding protein with hormone-sensitive lipase. J Biol Chem. 2001; 276: 49443-8 